\title{
Evaluation of air pollution tolerance indices of four ornamental plants arranged along roadsides in Abidjan (Côte d'Ivoire)
}

\author{
Zamblé Fidèle Tra Bi ${ }^{1}$, Djédoux Maxime Angaman ${ }^{2,}$, , Yao Sadaiou Sabas Barima ${ }^{3}$, \\ Bini Kouamé Dongui ${ }^{3}$
}

${ }^{1}$ UFR Sciences et Gestion de l'Environnement, Université Nangui Abrogoua, Abidjan, Côte d'Ivoire

${ }^{2}$ UFR Agroforesterie, Université Jean Lorougnon Guédé, Daloa, Côte d'Ivoire

${ }^{3}$ UFR Environnement, Université Jean Lorougnon Guédé, Daloa, Côte d'Ivoire

Email address:

angamanmaxime@yahoo.fr (D. M. Angaman)

To cite this article:

Zamblé Fidèle Tra Bi, Djédoux Maxime Angaman, Yao Sadaiou Sabas Barima, Bini Kouamé Dongui. Evaluation of Air Pollution Tolerance Indices of Four Ornamental Plants Arranged Along Roadsides in Abidjan (Côte d'Ivoire). International Journal of Environmental Monitoring and Analysis. Vol. 3, No. 1, 2015, pp. 22-27. doi: 10.11648/j.ijema.20150301.14

\begin{abstract}
The development of urbanization and industrialization contributes to ambient air pollution of the city of Abidjan. Air pollution can affect plants morphology and physiology. Plants can absorb gaseous and particulates pollutants through leaves, they tend to show some symptoms according to their level of sensitivity after exposure to the air pollution. In order to evaluate the susceptibility level of plants to air pollutants, four biochemical and physiological parameters, namely; ascorbic acid, chlorophyll, relative water content and leaf extract $\mathrm{pH}$ were determined and computed together in a formulation of air pollution tolerance indices (APTI) of Ficus benjamina, Jatropha integerrima, Cassia surattensis and Barleria prionitis arranged along main roads (MR) as well as in parks (P) as control in Abidjan. APTI values for overall species are ranged between 9.78 to 17.15 in P and from 9.76 to 16.91 in MR. The highest APTI is observed in Ficus benjamina and lowest in Cassia surattensis. Ficus benjamina was categorized as intermediate tolerant specie; and Jatropha integerrima, Barleria prionitis were categorized as intermediate sensitive species contrary to Cassia surattensis which was sensitive specie. Thus, tropical urban air quality evaluation is possible by using plants APTI.
\end{abstract}

Keywords: Air Pollution, Air Pollution Tolerance Index, Main Roads, Côte d'Ivoire

\section{Introduction}

The rapid urbanization and growing industrialization in the world during the last decades led to increasing levels of air pollution [1] dwindling urban air quality [2] .

Plants play an important role in monitoring and maintaining the ecological balance by their involvement in the cycling of nutrients and gases like carbon dioxide and oxygen [3]. However, air pollutants like gases and particulate matters cause environmental stress in plants which can change their leaf structure and physiology $[4,5,6]$. Air pollutants can alter the leaf epidermis [7] and affect stomatal conductance [8].

The physiological and biochemical responses of plants to air pollution can be understood by analyzing the factors determining resistance and susceptibility [9]. Plants sensitivity and tolerance to air pollutants varie with change in leaf extract $\mathrm{pH}$, relative water content, ascorbic acid content and total chlorophyll content [10]. Ascorbate was known as an antioxidant molecule able to detoxify air pollutants [11] and it is also able to control cell expansion and cell division $[12,13]$. Chlorophyll is essential for the vital process of photosynthesis in green plants. Changes in leaf chlorophyll can serve as relative indicators of environmental quality [14]. The importance of $\mathrm{pH}$ in mediating physiological responses to stress was another reason in including it in air pollution tolerance index component [15].

Single parameter may not provide a clear explanation of the pollution-inducted changes, [16] used these four parameters for identifying tolerance levels of plant species 
like Artocarpus sp., Eucalyptus sp., Citrus lemon, Azadirachta indica, Rosa indica, Aegle marmelos and Mangifera indica. To the term of their works Mangifera indica showed a tolerance to air pollution while Artocarpus $s p$ was identified as a sensitive specie. Sensitive plant species are suggested as bio-indicators [17].

Based on plant susceptibility in atmospheric pollution context, this study is based on the hypothesis according to which the physiological and biochemical parameters of the leaves of Ficus benjamina, Jatropha integerrima, Cassia surattensis and Barleria prionitis can be used for biomonitoring of air quality. To test this hypothesis, this study has for objective to determine tolerance or sensitivity of four plants species quoted above in urban habitats with a contrasting environmental quality. We will oppose main roads with high traffic activity (considered like polluted sites) to the parks (considered like less polluted sites). This typical classification has already been achieved by $[2,1]$.

\section{Materials and Methods}

\subsection{Study Area}

The city of Abidjan - the economic capital of Ivory Coast - was selected as study. Abidjan is situated on the south-east of the country in the Gulf of Guinea ( $5^{\circ} 00^{\prime}-5^{\circ} 30 \mathrm{~N}, 3^{\circ} 50^{\prime}-$ $\left.4^{\circ} 10^{\prime} \mathrm{W}\right)$. The city has a tropical climate with a long rainy season from May through July, a small rainy season (September-November) and two dry seasons in between.

The city has main industries of the Ivory Coast and an automobile park constituted in majority of secondhand vehicles. Its firms are specialized in various domains of which the oil products and its derivatives, textile and the agroalimentary. Traffic density and industrial smokestacks could be potential sources of pollution.

The city of Abidjan also contains several parks of which a national park, a botanical garden and a floristic center. In these green areas, the human influence is relatively weak and activities of pollution are most controlled relatively to the industrial areas and road traffic.

\subsection{Preparation of Experimental Plant Samples}

We used four plant species which were usually used as ornamental and roadside plants, Ficus benjamina, Jatropha integerrima, Cassia surattensis and Barleria prionitis. All tree species were obtained and grown in a garden of the city. All plants were grown in $30 \mathrm{~cm}$ diameter, $27 \mathrm{~cm}$ height plastic pots. The Medium was a mixture of compost and soil. The plants were grown for three months until reaching $140-180 \mathrm{~cm}$.

\subsection{Experimental Set $U p$}

The experimental pots were placed in the vicinity of main roads (4 sites) of Abidjan highways and in parks ( 2 sites) during three months. Within main roads the pots were arranged in three rows separated about two meters between the rows. Each row was consisted of height pots (four pots in two replicates). The distance between two pots was $1 \mathrm{~m}$ and between two replicates in the same rows was $1 \mathrm{~m}$.

\subsection{Leaf Sampling}

The mature leave samples were collected in July 2013 at the end of the long rainy season during 2 days. Samples were collected in early morning and brought to laboratory in polythene bag kept in the liquid nitrogen box. In the laboratory, samples were preserved in a refrigerator for further biochemical analyses. The leaves were carried out from a height of 1 to $2 \mathrm{~m}$ from the ground level.

\subsection{Relative Water Content (RWC)}

With the method as described by [18], leaf relative water content was determined and calculated with the formula:

$$
\begin{gathered}
\mathrm{RWC}=[(\mathrm{FW}-\mathrm{DW} / \mathrm{TW}-\mathrm{DW})] \times 100 \\
\mathrm{FW}=\text { fresh weight }, \\
\mathrm{DW}=\text { dry weight and } \\
\mathrm{TW}=\text { turgid weight. }
\end{gathered}
$$

Fresh weight was obtained by weighing fresh leaves. The leaves were then immersed in water overnight, blotted dry and weighed to get turgid weight. Now the leaves were dried in an oven at $70^{\circ} \mathrm{C}$ and reweighed to obtain dry weight.

\subsection{Total Chlorophyll Content (TCH)}

This was done according to the method described by [19]. $3 \mathrm{~g}$ of fresh leaves were blended and then extracted with 10 $\mathrm{ml}$ of $80 \%$ acetone and left for $15 \mathrm{~min}$. The liquid portion was decanted into another tube and centrifuged at $2500 \mathrm{rpm}$ for $3 \mathrm{~min}$. The supernatant was then collected and the absorbance was then taken at $646.6 \mathrm{~nm}$ and $663.6 \mathrm{~nm}$ using a spectrophotometer. Calculations were made using the formula below:

$$
\begin{aligned}
& \text { Chlorophyll a }(\mathrm{mg} / \mathrm{g})=12.25(\mathrm{~A} 663.6)-2.55(\mathrm{~A} 646.6) \\
& \text { Chlorophyll b }(\mathrm{mg} / \mathrm{g})=20.31(\mathrm{~A} 646.6)-4.91(\mathrm{~A} 663.6) \\
& T C H(\mathrm{mg} / \mathrm{g})=17.76(\mathrm{~A} 646.6)+7.34(\mathrm{~A} 663.6)
\end{aligned}
$$

\subsection{Ascorbic Acid Content (AA)}

Ascorbic acid content of the samples were determined by using tritimetric method described by [20]. $5 \mathrm{~g}$ of the sample was weighed into an extraction tube and $100 \mathrm{ml}$ of EDTA/TCA $(2: 1, \mathrm{v} / \mathrm{v})$ were added. The homogenate was shaken during $30 \mathrm{~min}$ and centrifuged at $3000 \mathrm{rpm}$ for 20 min. The supernatant was transferred into a flask and $20 \mathrm{ml}$ was pipetted into a volumetric flask and $1 \%$ starch indicator was added and titrated with $20 \% \mathrm{CuSO}_{4}$.

\subsection{Leaf Extract pH}

For $\mathrm{pH}$ estimation $5 \mathrm{~g}$ of the fresh leaves was homogenized in $10 \mathrm{ml}$ deionised water. The extract was 
filtered and the $\mathrm{pH}$ was determined after calibrating $\mathrm{pH}$ meter with buffer solution of $\mathrm{pH} 4$ and $\mathrm{pH} 9$ [21].

\subsection{Air Pollution Tolerance Index (APTI) Determination}

The air pollution tolerance indices were determined following the method of [22]. The formula of APTI is given as

$$
\mathrm{APTI}=[\mathrm{A}(\mathrm{T}+\mathrm{P})+\mathrm{R}] / 10
$$

$\mathrm{A}=$ Ascorbic acid content $(\mathrm{mg} / \mathrm{g})$,

$\mathrm{T}=$ total chlorophyll content $(\mathrm{mg} / \mathrm{g})$,

$\mathrm{P}=\mathrm{pH}$ of leaf extract and

$$
\mathrm{R}=\text { relative water content of leaf }(\%) \text {. }
$$

On the basis of APTI values, plants were categorized into three groups [22].

i) Sensitive species: APTI $<10$; ii) Intermediate species: APTI among 10-16 ; iii) Tolerant species: APTI $>17$

\subsection{Statistical Analysis}

We used STATISTICA 7.1 software, to make correlation between biochemical parameters and also with APTI values, and find linear regression.

\section{Results and Discussion}

Table 1. Means of relative water content (RWC), leaf extract pH, total chlorophyll (TCH) and acid ascorbic (AA) of four plant species in two land uses

\begin{tabular}{lllllllll}
\hline \multirow{2}{*}{ Land use classes } & \multicolumn{2}{l}{ Barleria prionitis } & \multicolumn{2}{l}{ Cassia surattensis } & \multicolumn{2}{l}{ Jatroffa integerrina } & \multicolumn{2}{l}{ Ficus benjamina } \\
\cline { 2 - 9 } & P (control) & MR & P (control) & MR & P (control) & MR & P (control) & MR \\
\hline RWC $(\%)$ & 70 & 77.9 & 63.61 & 66.99 & 77.65 & 70.2 & 90 & 80.09 \\
pH & 8.05 & 7.37 & 5.49 & 5.33 & 7.21 & 6.52 & 7.79 & 7.53 \\
TCH $(\mathrm{mg} / \mathrm{g})$ & 1.03 & 0.67 & 1.61 & 0.8 & 1.07 & 1.04 & 1.47 & 0.91 \\
$\mathrm{AA}(\mathrm{mg} / \mathrm{g})$ & 4.8 & 6.4 & 5 & 4.8 & 6.8 & 8.33 & 8.8 & 10.56 \\
\hline
\end{tabular}

The air pollution tolerance indices (APTI) were determined for 4 plant species (Ficus benjamina, Jatropha integerrima, Cassia surattensis and Barleria prionitis) in 2 land use classes (parks and main roads). All biochemical parameters analyzed for the APTI played an important role to determine species tolerance or sensitivity to the atmospheric stress.

According to table 1, the average leaf relative water content (RWC) varied from $63.61 \%$ to $90 \%$ in $\mathrm{P}$ and from $66.99 \%$ to $80.09 \%$ in main roads (MR). In polluted sites (MR), the RWC values were the highest in F. benjamina and the lowest in C.surattensis. Reduction in relative water content of plant species is due to impact of pollutants on transpiration rate in leaves [23]. It has been reported that air pollutants increase cell permeability [24], which cause loss of water and dissolved nutrients, resulting in early senescence of leaves [25]. According to [26], RWC ranged between $58 \%$ to $73 \%$ in intermediately tolerant species and $51.3 \%$ to $84 \%$ in sensitive plant species.

The $\mathrm{pH}$ of leaf extract, oscillated between 5.33 ( $C$. surattensis) to 7.53 ( $F$. benjamina) at polluted sites and from 5.49 (C. surattensis) to 8.05 (B. prionitis) in less polluted sites (P). Thus [27], reported that in the presence of an acidic pollutant, the leaf $\mathrm{pH}$ is lowered and the decline is greater in sensitive than that in tolerant plant. High $\mathrm{pH}$ may increase the efficiency of conversion from hexose sugar to ascorbic acid, a natural antioxidant [3]. The $\mathrm{pH}$ ranged between 4.4 and 8.8 lies in both intermediately tolerant and sensitive plant species [26].

Total chlorophyll content ranged from $0.8 \mathrm{mg} / \mathrm{g}(C$. surattensis) to $1.04 \mathrm{mg} / \mathrm{g}$ (J. integerrima) in MR and from $1.03 \mathrm{mg} / \mathrm{g}$ (B. prionitis) to $1.61 \mathrm{mg} / \mathrm{g}$ (C. surattensis) in P. A study conducted by [28] suggested that the chlorophyll level in plants decreases under pollution stress. According to [26], the plants having Chlorophyll content between 4 to $16 \mathrm{mg} / \mathrm{g}$ are categorized as intermediately tolerant plant species.

Ascorbic acid content of species varied between 4.8 to $10.56 \mathrm{mg} / \mathrm{g}$ in MR and between 4.8 to $8.8 \mathrm{mg} / \mathrm{g}$ in $\mathrm{P}$. Ascorbic acid content in polluted area is highest in $F$. benjamina and lowest in $B$. prionitis.

A great correlation between ascorbic acid content and resistance to pollution exist in plants [32]. Resistant plants contain high amount of ascorbic acid, while sensitive plants possess a low level.

The ascorbic acid is natural detoxicant, which may prevent the damaging effect of air pollutants in plant tissues [29] and high amount of this substance favors pollution tolerance in plants [30,31]. Level of this acid declines on pollutant exposure [30]. The ascorbic acid content ranged between 7.52 to $11.05 \mathrm{mg} / \mathrm{g}$ in intermediately tolerant species and 1.61 to $8.23 \mathrm{mg} / \mathrm{g}$ among the sensitive plant species [26].

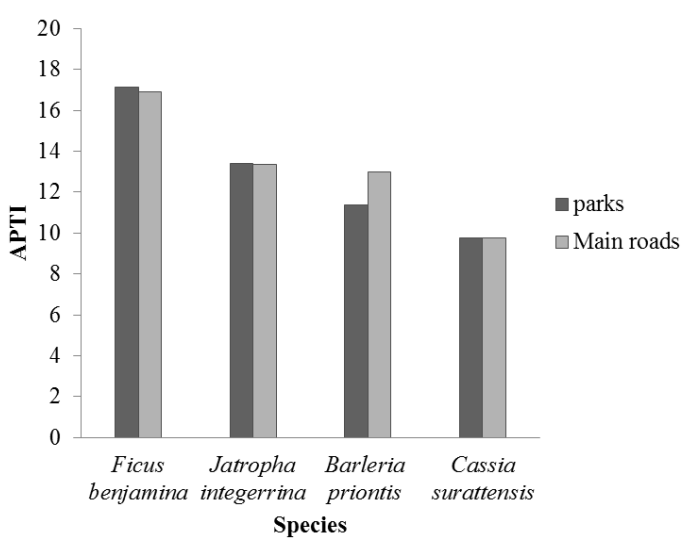

Figure 1. Comparison of air pollution tolerance Index (APTI) of four plants in land use classes. 
The APTI values (Fig.1) obtained for different plants ranges from 9.76 to 17.15 at Polluted sites and oscillate from 9.78 to 16.91 in unpolluted sites. Air pollution tolerance index values were found to be greater in Ficus benjamina and least in Cassia surattensis.

The correlation matrix given in table 2 shows the association of the four biochemical parameters among themselves and also with the dependent parameter APTI whereas the figure 2 shows the linear regression plots individual variables with APTI. It is observed that a high positive correlation exists between APTI and relative water content $(\mathrm{r}=0.81 ; \mathrm{p}<0.05)$ as well as ascorbic acid content $(\mathrm{r}=0.92 ; \mathrm{p}<0.01)$.

Correlations between APTI and $\mathrm{pH}(\mathrm{r}=0.67 ; \mathrm{p}>0.05)$ as total chlorophyll content $(\mathrm{r}=0.35 ; \mathrm{p}>0.05)$ were not significant. Strong correlation $(r=0.79 ; p<0.05)$ is observed between relative water content and ascorbic acid content contrary to other parameters. The results show that the ascorbic acid content and the relative water content are the most significant and determinant factors of the leaves to the tolerance of the different species.

Table 2. Correlation matrix of biochemical variables and APTI of analyzed samples

\begin{tabular}{llllll}
\hline & RWC & Chlorophyll & pH & Ascorbic acid & APTI \\
\hline RWC & 1 & -0.33 & 0.51 & $0.79^{*}$ & $0.81^{*}$ \\
Chlorophyll & & 1 & -0.64 & -0.33 & 0.35 \\
pH & & 1 & 0.43 & 0.67 & $0.92^{* *}$ \\
Ascorbic acid & & & 1 & 1 \\
APTI & & & & 1 \\
\hline
\end{tabular}

*: Significantly different at $\mathrm{p}<0.05 . * *$ : Significantly different at $\mathrm{p}<0.01$.
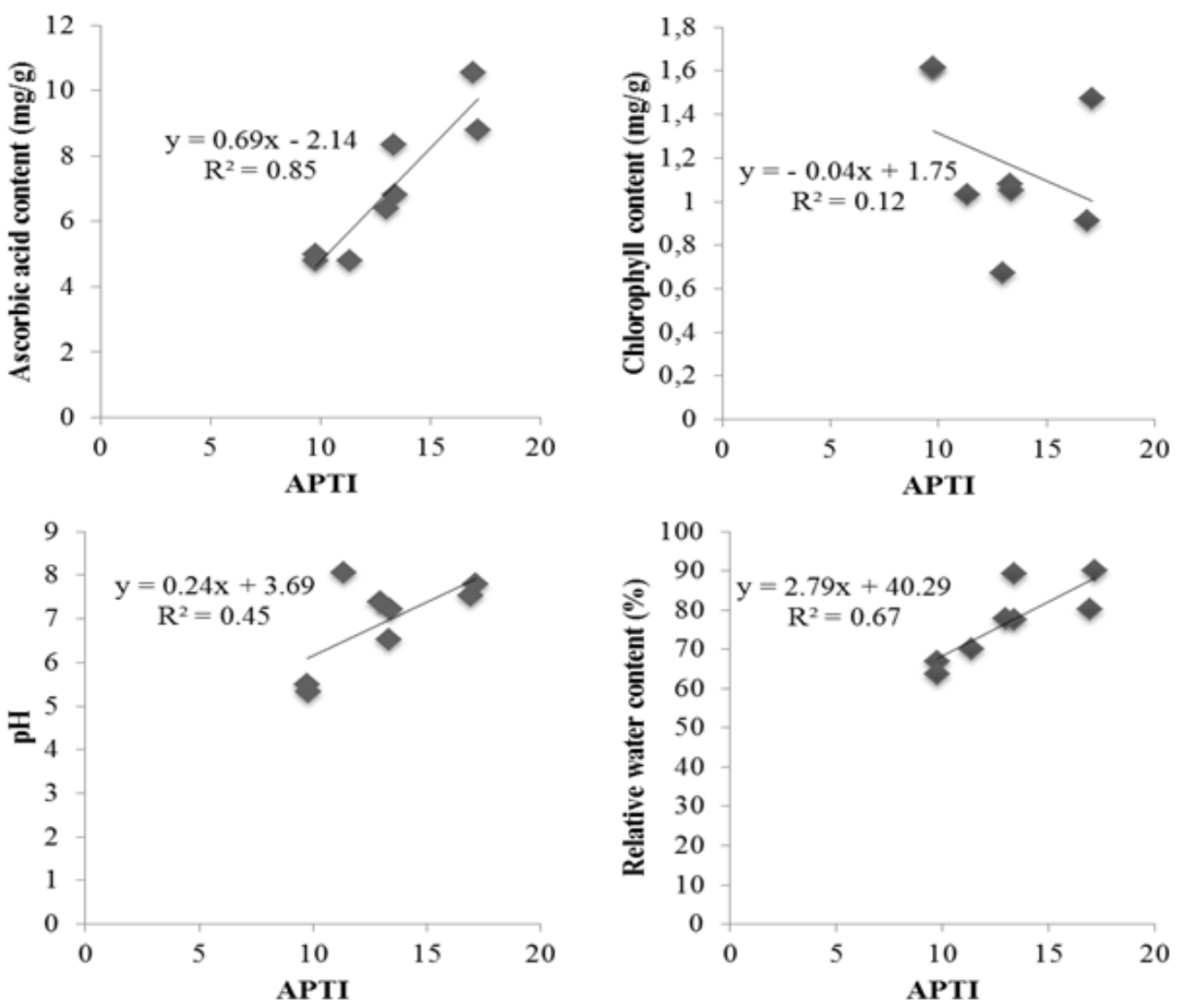

Figure 2. Correlation between biochemical parameters(ascorbic acid, chlorophyll, $p H$, relative water content) and APTI

\section{Conclusions}

The present study allowed to estimate air quality of the city of Abidjan from biochemical parameters (chlorophyll, ascorbic acid, $\mathrm{pH}$ and relative content in water) measured in four plant species. All parameters allowed to assess plants physiology response to atmospheric pollution. Their combination permitted to determine the APTI of the different plants studied and reveal the intermediate tolerance of Ficus benjamina, the intermediate sensitivity of Jatropha integerrima and Barleria prionitis and the sensitivity of Cassia surattensis to atmospheric pollution. Besides the positive correlation between ascorbic acid content, relative 
water content and APTI proved to be significant showing their importance in plants in stress environment.

This study showed that it is possible to achieve a bioindication of air quality from biochemical parameters of leaves in African tropical environment.

\section{Acknowledgements}

This work was support by grants of International Foundation for Science (IFS) and Ivorian institution "Programme d'Appui Stratégique à la Recherche Scientifique" (PASRES) to the second author. The third author is a beneficiary of a mobility grant from the Belgian Federal Science Policy Office (BELSPO) co-funded by the Marie Curie Actions from the European Commission. We also thanks the city council of "District Autonome d'Abidjan" for their assistance in achieving field data.

\section{References}

[1] F. Kardel, K. Wuyts, M. Babanezhad, U. W. A Vitharana, T. Wuytack, G. Potters and R. Samson, "Assessing urban habitat quality based on specific leaf area and stomatal characteristics of Plantago lanceolata L". Environmental Pollution, 2010, v. 158, p.788-794.

[2] B. L. W. K. Balasooriya, R. Samson, F. Mbikwa, W.A.U. Vitharana, P. Boeckx and M. Van Meirvenne, "Bio-monitoring of urban habitat quality by anatomical and chemical leaf characteristics". Environmental and Experimental Botany, 2009, v. 65, p. 386-394.

[3] F.J. Escobedo, J.E. Wagner and D.J. Nowak, "Analyzing the cost effectiveness of Santiago, Chile's policy of using urban forests to improve air quality". 2008, Journal of Environmental Management, v. 86, p. 148-157.

[4] M. Rajput and M. Agrawal, "Bio-monitoring of air pollution in a seasonally dry tropical suburban area using wheat transplants". Environmental Monitoring and Assessment, 2005, v. 101, p. 39-53.

[5] G. Klump, C. M. Furlan and M. Domingos, "Response of stress indicators and growth parameters of tibouchina pulchra logn. Exposed to air and soil pollution near the industrial complex of cubatao, Brazil’. Sci. Total Environ, 2000, v. 246, p. 79-91.

[6] Y. S. S. Barima, D. M. Angaman, K. P. N'Gouran, N.A. Koffi, F. Kardel, C. De Cannière and R. Samson, "Assessing atmospheric particulate matter distribution based on saturation isothermal remanent magnetization of herbaceous and tree leaves in a tropical urban environment". Science of the Total Environment, 2014, v. 471, p. 975-982.

[7] I. Gostin, "Air pollution effects on the leaf structure of some Fabaceae Species". Not. Bot. Hort. Agrobot. Cluj, 2009, v. 37 (2), p. 57-63.

[8] A. Verma and S. Singh, "Biochemical and ultrastructural changes in plant foliage exposed to auto-pollution". Environmental Monitoring and Assessment, 2006, v. 120, p. 585-602.
[9] S.M. Seyyednejad, K. Majdian, H. Koochak and M. Nikneland, "Air pollution Tolerance Indices of some plants around Industrial Zone in South of Iran". Asian Journal of biological Sciences, 2011, v. 4 (3), p. 300-305.

[10] A. Chouhan, S. Iqbal, R.S. Maheswari, A. Bafna, "Study of air pollution index of plants growing in Pithampur Industrial area sector 1, 2 and 3". Res. J.Recent. sci, 2012, v. 1, p. 172-177.

[11] N. Smirnoff, "The function and metabolism ascorbic acid in plants". Ann Bot, 1996, v. 78, p. 661-669.

[12] F. A. Loewus, "Biosynthesis and metabolism of ascorbic acid in plants and an analogs of ascorbic acid in fungi". Phytochemistry, 1999, v. 52, p. 193-210.

[13] Conklin, "Identification of ascorbic acid-deficient Arabidopsis thaliana mutants". Genetics, 2000, v. 154, p. 847-856.

[14] G.A. Carter and A.K. Knapp, "Leaf optical properties in higher plants: linking spectral characteristics to stress and chlorophyll concentration". Am J Bot, 2001, v. 88, p. 677-684.

[15] W. Hartung, J. W. Radin and D.L. Hendrix, "Absisic acid movement into the apoplastic solution of water stressed cotton leaves". Plant Physiol, 1988, v. 86, p. 908-913.

[16] K. Mohammed, K. Rashmi and W.R. Pramod, "Studies on air pollution tolerance of selected plants in Allahabad city, India”. E3. J. Environ. Res. Manage, 2011, v. 2 (3), p. 42-46.

[17] K.S. Arun, "India's urban growth and environmental concern". J. Environ. Res. Develop, 2008, v. 1 (1), p. 73-78.

[18] Y.J. Lui and H. Ding, "Variation in air pollution tolerance index of plants near a steel factory, Impication for landscape plants species selection for industrial areas", WSEAS Trans. On Environ. and Develop, 2008, v. 4, p. 24-32.

[19] R.J. Porra, "The chequered history of the development and use of simultaneous equations for the accurate determination of chlorophylls a and b". Photosynth Res, 2002, v. 73, p. 149-156.

[20] M.Z. Barakat, S.K. Shehab, N. Darwish and E.I. Zahermy, "Ascorbic Acid from plants". Anal. Biochem, 1973, v. 53, p. 225-245.

[21] P.O. Agbaire, "Air Pollution Tolerance Indices (APTI) of some plants around Erhoike- Kokori oil exploration in Delta state, Nigeria”. J. Applied Sci. Environ.Manage, 2009, v. 4 (6), p. 366- 368.

[22] S.K. Singh and Rao D.N, "Evaluation of plants for their tolerance for their tolerance to air pollution, In : proceedings symbosium on Air pollution control, Indian association of Air pollution control, New Delhi, India, 1983, V. 1, p. 218-224.

[23] A. Swami, D. Bhatt and P.C. Joshi, "Effects of automobile pollution on sal (Shorea robusta) and rohini (Mallotus phillipinensis) at Asarori, Dehradun". Himalayan Journal of Environment and Zoology, 2004, v. 18 (1), p. 57-61.

[24] T. Keller, "The electrical conductivity of Norway spruce needle diffusate as affected by air pollutants". Tree Physiol, 1986, v. 1, p. 85-94. 
[25] G. Masuch, H. Kicinski, A. Kettrup and K.S. Boss, "Single and combined effects of continuous and discontinuous $\mathrm{O}_{3}$ and $\mathrm{SO}_{2}$ emission on Norway spruce needle: Histochemical and cytological changes". Intl. J. Env. Anal. Chem, 1988, v. 32 , p. $213-241$

[26] P.S. Lakshmi, K.L. Sravanti and N. Srinivas, "Air pollution tolerance index of various plant species growing in industrial areas". The Ecoscan, 2008, v. 2 (2), p. 203-206.

[27] F. Scholz and S. Reck, "Effects of acids on forest trees as measured by titration in vitro, inheritance of buffering capacity in Picea abies". Water, Air and Soil Pollut, 1977, v. 8, p. 41-45.

[28] D.J. Speeding and W.J. Thomas, "Effect of sulphur dioxide on the metabolism of glycollic acid by barley (Hardeum vulgare) leaves". Aust. J. Biol. Sci, 1973, v. 6, p. 281-286.
[29] S.K. Singh, D.N. Rao, M. Agrawal, J. Pandey and D. Narayan, "Air pollution tolerance index of plant". J Environ Mgmt, 1991, v. 32, p. 45-55.

[30] T. Keller and H. Schwager, "Air pollution and ascorbic acid". Eur. J. Forestry Pathol, 1977, v. 7, p. 338-350.

[31] E.H. Lee, J.A. Jersey, C. Gifford and J. Bennett, "Differential ozone tolerance in soybean and snapbeans: analysis of ascorbic acid in $\mathrm{O}_{3}$ susceptible and $\mathrm{O}_{3}$ resistant cultivars by high performance liquid chromatography". Env. Expl. Bot, 1984 , v. 24, p. 331-341.

[32] S.R.K. Varshney and C.K. Varshney, "Effect of $\mathrm{SO}_{2}$ on ascorbic acid in crop plants". Env. Pollut, 1984, v. 35, p. 285-290. 